\title{
Termites and agricultural production in the Sahel: from enemy to friend?.
}

A. MANDO* AND T. VAN RHEENEN

Antenne Sahélienne, 01 BP 5385, Ouagadougou 01, Burkina Faso

* Corresponding author: fax: +226 3631 10; e-mail: antenne@ fasonet.bf

Received 22 August 1997; accepted 15 January 1998

\begin{abstract}
Increasingly, it is being recognized that termites are an important component of agroecosystems, particularly in developing countries where they are an alternative to high priced inputs. Given the major problems in the Sahel of soil crusting and nutrient depletion, this paper shows that termites associated with proper management techniques can play a vital role. Termites contribute to the rehabilitation of crusted soils, i.e. by opening up voids on the sealed surface leading to improved infiltration capacity, and consequently improved water availability. It is recommended, however, that participatory on-farm research should be carried out on how to increase the contribution of termites towards soil management and to reduce the harmful effects.
\end{abstract}

\section{Résumé}

Il est de plus en plus reconnu que les termites constituent une composante importante des agroécosystèmes, cela particulièrement dans les pays en développement où ils sont une alternative aux intrants agricoles qui sont très coûteux. En raison des problèmes majeurs que sont l'encroûtement des sols et l'épuisement des éléments nutritifs des sols dans le Sahel, cet article montre qu'associé à des techniques appropriées de gestion des sols, les termites peuvent jouer un rôle majeur. Les termites contribuent à la réhabilitation des sols encroûtés, par exemple en ouvrant sur leurs surfaces colmatées des macropores entraîneraient une augmentation de la capacité d'infiltration et par conséquent une augmentation de la disponibilité en eau du sol. Il est cependant recommandé, que soit conduites des recherches participatives en milieu paysan afin d'augmenter la contribution des termites dans la gestion des sols et de minimiser leurs effets négatifs.

\author{
Keywords: \\ Mots clés: \\ Termites, Sahel, rehabilitation, sustainable management, crusted soils, water availability \\ Termites, Sahel, réhabilitation, gestion durable, sols encroûtés, disponibilité en eau
}

\section{Introduction}

The demand in the Sahel for suitable agricultural techniques and methods have never before been so high, due to the increasing population pressure and the unprecedented rate of soil degradation. To solve the problems that confront the rural area's in the Sahel, secure food production, and to curtail further soil degradation, a set of measures will have to be taken. These may range from re-evaluating and adjusting macro-economic policies to the implementation of simple measures at the farm household level. Amongst others, this requires that the productivity of the arable land will increase and also that the area of land under cultivation or pasture will extend at the expense of wasteland (Kaboré, 1994, Mando, 1997a). It has been well established that the lack of adequate water supply due to soil physical degradation (soil crusting) and unreliable rainfall, and nutrient shortage are the principal constraints to crop production in arid and semi-arid regions (Bationo \& Mokwunye, 1991; Lal, 1987; Mando et al., 1996). Therefore, soil management to improve crop production should address both. However, it is noted that the Sahel is one of the world's poorest regions. Consequently, any new innovations can only be adopted when they are cheap and easily accessible. 
Termites are the most important soil fauna in the semi-arid tropics (Lobry De Bruyn \& Conacher, 1990). Despite the absence of literature on the economic damage they inflict on crops which is considered moderate compared to other pests (Iroko, 1996), they are, however, often regarded as pest because they attack roots and above ground plants, and stored food supplies (Iroko, 1996; Wood, 1996). On the other hand it is well known, that termites may have a great impact on soil properties and soil genesis. The dense network of their nests and galleries improves soil porosity and aeration (Humphreys, 1994; Lee \& Foster, 1991; Wielemaker, 1984), infiltration and water storage and, consequently, increases soil primary productivity (Elkins et al., 1986). Termites also play a key role in nutrient recycling (Bachelier, 1978; Basppa \& Rajagopal, 1991) and modify soil chemical characteristics by mixing soil from different layers. West African farmers, therefore, deliberately seek out land with many and large termite mounds or termite foraging areas for reasons of fertility or availability of soil water (Fairhead \& Leach, 1994). Finally, termite mounds or termites foraging areas are considered to influence vegetation successions and patterns, and fallow dynamics. Despite the relative abundance of data to ascertain the positive role that termites may play in improving soil fertility, there are very few agronomic experiments to confirm this role.

In this paper, we examine the role of termites in tackling soil physical degradation (especially soil crusting), which is one of the major agricultural problems in the Sahel (Valentin, 1995), and derive recommendations for extension services and for targeting future research.

\section{Termites ecology in the Sahel: general review}

Termites, animals of the order Isoptera are polymorphic social insects which live in nests (termitaria) and are ubisquistous in the Sahel (Lee \& Wood, 1971; Bachelier, 1978). The quality and availability of food determine the composition and the size of a termite population (Wood, 1996; Black and Ockwakol, 1997). On the basis of their food sources three main groups are distinguished:

1. live and dead plant material eaters,

2. humivorous termites, eating humus, and

3. fungal eaters.

In the Sahel, mainly plant material feeding termites occur. On the basis of their nesting behaviour, two main groups are further distinguished: building species and subterranean species. Nesting is determined by soil textural composition and other soil physical characteristics, such as presence of cracks. Termites cannot build stable structures (nests and galleries) on cracking soils.

\section{Materials and methods}

In Burkina Faso (West Africa) at Bourzanga ( $\left.13^{\circ} 26^{\prime} 15^{\prime \prime} \mathrm{N}, 1^{\circ} 37^{\prime} 30^{\prime \prime} \mathrm{W}\right)$, an experiment was conducted from June 1993 to November 1995. The experimental site receiving an average annual rainfall of $486 \mathrm{~mm}$ was fenced to exclude large free roaming animals. Soil and vegetation data were collected every year, and included vegetation cover, vegetation biomass, number of plant species, soil macropores $(0-120 \mathrm{~cm})$, saturated hydraulic conductivity, and water infiltration. The effect of mulch on termite population dynamics was indirectly assessed by monitoring termite-made macropores six months after mulch application.

A split plot design was used, one block on each of three soil types, Ferric Lixisols, Haplic Lixisols, and Chromic Cambisols. The main treatment was the use of an insecticide (Dieldrin at a rate of $500 \mathrm{~g} \mathrm{a.i} \mathrm{ha}^{-1}$ ) to compare the change in soil properties productivity in the presence of termites (T) and in the absence of termite (NT). Dieldrin, an organochlorine whose common name is HEOD, is a persistent and non-systemic insecticide of high contact and stomach activity to most insects (Charles, 1979). Dieldrin was used after Dursban EC (400 g a.i ha ${ }^{-1}$ ) had failed to keep termites away. Within the main plots $(50 \times 50 \mathrm{~m}$ and $50 \mathrm{~m}$ apart, two times four subplots $(15 \times 8 \mathrm{~m})$ with $8 \mathrm{~m}$ between the subplots were installed. The two groups of subplots in each main plots were $15 \mathrm{~m}$ apart. To stimulate termite activity mulching was randomly applied in the subplots. The treatments included: the control without mulch [B], Pennisetum pedicellatum straw applied at $3 \mathrm{tha}^{-1}[\mathrm{~S}]$, woody material of Pterocarpus lucens applied at $6 \mathrm{tha}^{-1}$ [W], and composite (woody material and straw, ratio of 1:2) treatments applied at $4 \mathrm{t} \mathrm{ha}^{-1}[\mathrm{C}]$, as described in detail by Mando (1997b). 


\section{Results and discussion}

\section{Mulch and termites activity}

Termite activity is triggered by the application of mulch on bare and crusted soils. The colonisation of that soil by termites takes places in a relatively short time (few weeks) independent of soil types, with about 65 macropores for wood and straw mulch and 126 for composite. The difference, however, is not significant $(P=0.05)$. Three species of termites were found in the experimental field (Odontotermes smeathmani (Fuller); Microtermes lepidus (Sjöst) and Macrotermes bellicosus (Sjöst)). Mando \& Miedema (1997) have established that Odontotermes smeathmani (Fuller) was responsible for the number of voids mentioned above.

\section{Termites and soil physical properties}

Termites had significant effects on soil structure (i.e. the number of voids), they opened up large and numerous macropores on the sealed surface of the soil. The macropores (i.e. channels and chambers) resulted from the nesting and foraging activities of termites. The size of the macropores and their density per unit soil surface depended on termites species, population size, and the contact points between the organic material and the soil. As reported elsewhere (Mando \& Miedema, 1997) termites excavate irregular- shaped macropores throughout the entire soil profile, and the area occupied by these macropores was up to $12 \%$ of the soil in the $0-7 \mathrm{~cm}$ horizon, accounting for $60 \%$ of the macroporosity in that horizon.

Table 1. Effect of termites and mulch on soil porosity and saturated hydraulic conductivity (Ksat). TS= termite straw, $\mathrm{TC}=$ termite composite, $\mathrm{TW}=$ termite woody material, $\mathrm{B}=$ Termite bare, $\mathrm{NTC}=$ non termite composite, $\mathrm{NTS}=$ non termite straw, NTW= non termite woody material. $[\mathrm{T}]=$ termite plots, $[\mathrm{NT}]=$ non termite plots. Treatments having the same letter(s) are not statistically different at $P=0.01$.

Tableau 1. Effet de l'activité des termites et du paillage sur la porosité du sol et la conductivité hydraulique saturée (Ksat). $\mathrm{TS}=$ termites+paille, $\mathrm{TC}=$ termites+paille+bois; $\mathrm{TW}=$ termites+bois, $\mathrm{B}=\mathrm{sol}$ nu (témoin). $\mathrm{NTS}=$ paille sans termites, $\mathrm{NTC}=$ paille+bois sans termites; NTW=bois sans termites. Les traitements portant les mêmes lettres ne sont significativement différents au seuil $P=0.01$.

\begin{tabular}{|c|l|l|}
\hline & Porosity $(\%)$ & Ksat $\left(10^{-5} \mathrm{~m} \mathrm{~s}^{-1}\right)$ \\
\hline TC & $41.48 \mathrm{a}$ & $3.56 \mathrm{a}$ \\
\hline TW & $41.10 \mathrm{a}$ & $1.06 \mathrm{a}$ \\
\hline TS & $42.03 \mathrm{a}$ & $0.47 \mathrm{a}$ \\
\hline B & $36.10 \mathrm{a}$ & $0.14 \mathrm{~b}$ \\
\hline NTC & $38.50 \mathrm{a}$ & $0.34 \mathrm{~b}$ \\
\hline NTS & $36.58 \mathrm{a}$ & $0.23 \mathrm{~b}$ \\
\hline NTW & $39.60 \mathrm{a}$ & $0.15 \mathrm{~b}$ \\
\hline
\end{tabular}

The study clearly demonstrated the significant role of termites in modifying crusted-soil characteristics. The number of voids open to the surface and soil porosity were greater on $(\mathrm{T})$ plots than on (NT) plots $(P<0.01)$. The saturated hydraulic conductivity was greatly improved on plots with termites and mulch, but remained unchanged on mulched plots without termites (Table 1). This confirms and explains earlier findings of Chase \& Boudouresque (1987) who have established that a single termite-made void is able to drain during $30 \mathrm{~min}, 100 \mathrm{~mm} \mathrm{~h}^{-1} \mathrm{~m}^{-2}$ of rainfall. As described elsewhere (Mando et al., 1996), the change in soil structure due to termites reduces runoff through:

1. a delay in time to ponding,

2. reducing the speed of the decline of infiltration rate with cumulative rainfall amount, and

3. increasing the overall infiltration rate.

The increase in infiltration on termite plots (Table 2) results into an increase of soil water content throughout the soil profile and throughout the growing period of the year (Figure 1). The figure illustrates that mulch improves soil water content through protecting the soil against the weather impact (evaporation), and increases the infiltration through its many tiny barriers. It is noted that the effectiveness of mulch depends on the covering, which declines in time due to decomposition. The decomposition rate of mulch is in turn a function of chemical and physical 
characteristics (Berendse et al., 1987). Materials with low high $\mathrm{C} / \mathrm{N}$ and high lignin or polyphenol content decompose slowly than material with low $\mathrm{C} / \mathrm{N}$.

Table 2. Effect of termites on soil water infiltration ( $\mathrm{I}$ in $\mathrm{mm}$ ) and infiltration efficiency $\mathrm{IE}(\% \mathrm{P})$. T $=$ termite, NT $=$ no termites (Mando, 1997b).

Tableau 2. Effet des termites sur l'infiltration de l'eau dans le sol (I en mm) et sur l'efficaté d'infiltration EI $(\% \mathrm{P})$. $\mathrm{T}=$ termites, NT = sans termites (Mando, 1997b).

\begin{tabular}{|l|l|l|l|l|l|}
\hline \multicolumn{2}{|c|}{} & I (mm) & IE (\%) & P & cv (\%) \\
\hline 1993 & T & $148 \mathrm{a}$ & 32 & 0.03 & 20.4 \\
\cline { 2 - 6 } & NT & $98 \mathrm{~b}$ & 21 & & \\
\hline 1994 & T & $429 \mathrm{a}$ & 53 & $<0.01$ & 15.3 \\
\cline { 2 - 5 } & NT & $300 \mathrm{~b}$ & 37 & & \\
\hline 1995 & T & $334 \mathrm{a}$ & 69 & & \\
\hline & NT & $247 \mathrm{~b}$ & 51 & & \\
\hline
\end{tabular}

Figure 1.

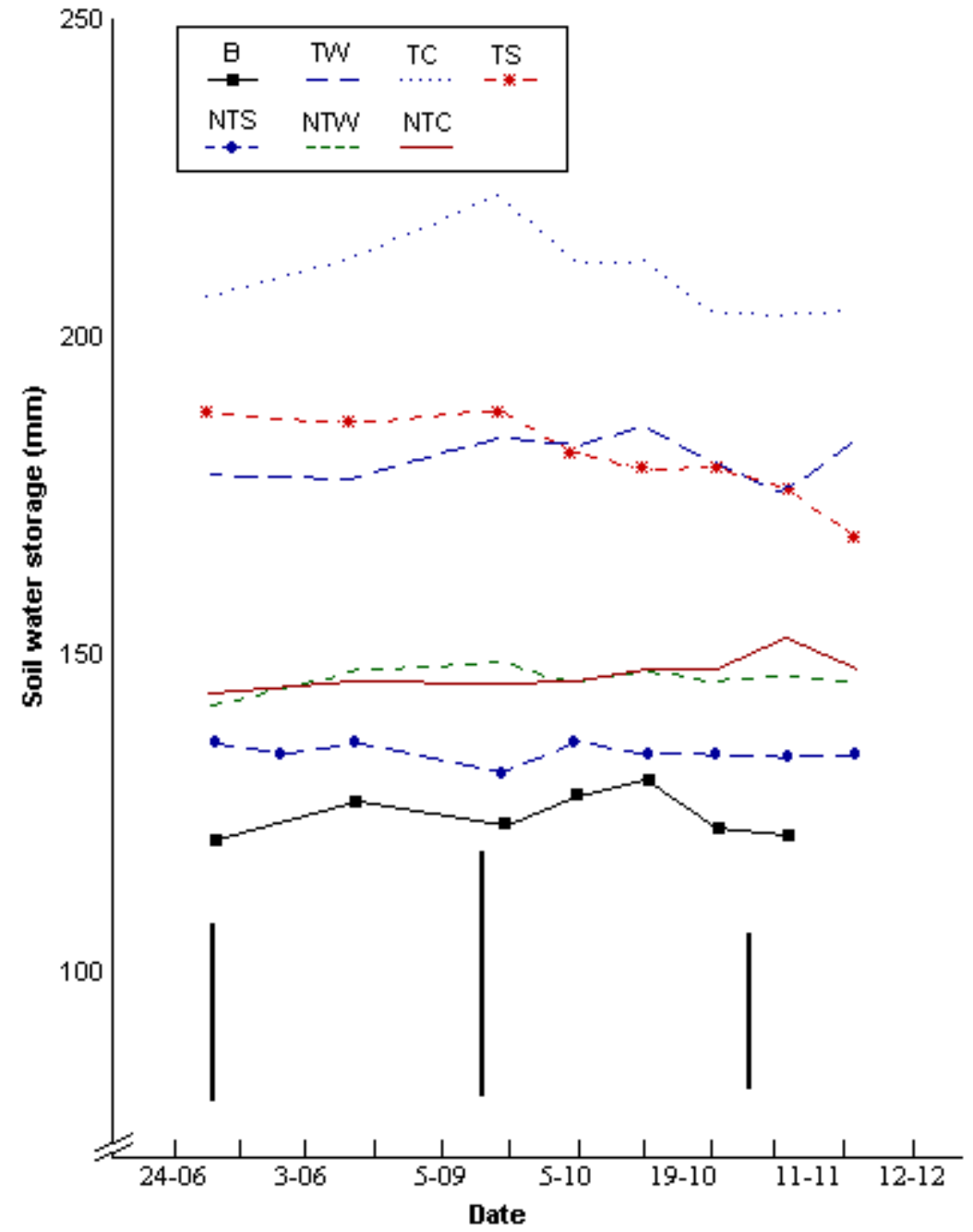

Figure 1. Effect of termite and mulch on soil water storage in 1995 rainy season. $\mathrm{TS}=$ termite straw, $\mathrm{TC}=$ termite composite, $\mathrm{TW}=$ termite woody material, $\mathrm{B}=$ bare, $\mathrm{NTC}=$ non termite composite, $\mathrm{NTS}=$ non termite straw, NTW= non termite woody material. Error bars in the figure represent LSD (0.05).

Figure 1. Effet des termites et du paillage sur le stock d'eau du sol pendant la saison humide de 1995. TS= termites+paille, $\mathrm{TC}=$ termites+paille+bois; $\mathrm{TW}=$ termites+bois, $\mathrm{B}=$ sol nu (témoin). $\mathrm{NTS}=$ paille sans termites, $\mathrm{NTC}=$ paille+bois sans termites; NTW= bois sans termites. Les barres d'erreurs sur la figure représentent les PPDS (0.05). 
Mulching a completely bare and crusted soil surface resulted within a year in the rehabilitation of primary production. Termite-mediated processes create conditions necessary and sufficient for both woody vegetation and herbs to re-establish. It has been proved (Mando et al., 1996) that the composite and straw mulches are associated with more termite activity features on soil than woody mulch. The degree of vegetation rehabilitation corresponded with the termite response (more vegetation on composite and straw mulched plots, less on woody plots and zero on bare plots). Weak herbs response was observed on [NT] plots, and woody vegetation failed to appear on these plots. Plant diversity, plant cover and biomass on mulched plots with termite activity were greater than on the plots without termite activity (Table $\underline{3}$ ). The statistical analysis of the effect of termites and mulch on natural vegetation and crop performance indicated a preponderant role of termites (the correlation between termites activity and crop performance had $r^{2}$ of 0.89 , whereas the correlation between mulch quality and crop performance only had an $r^{2}$ of $0.045)$.

Table 3. Effect of termites and mulch on vegetation parameters. TS = termite straw, TC =termite composite, TW= termite woody material, $\mathrm{B}=$ bare, $\mathrm{NTC}=$ non termite composite, $\mathrm{NTS}=$ non termite straw, NTW=non termite woody material, $* *=$ not measured. Treatments in the same column having the same letters are significantly not different (Mando, 1997a; adapted).

Tableau 3. Effet des termites et du paillage sur la végétation. $\mathrm{TS}=$ termites+paille, $\mathrm{TC}=$ termites+paille+bois; $\mathrm{TW}=$ termites+bois, $\mathrm{B}=$ sol nu (témoin). $\mathrm{NTS}=$ paille sans termites, $\mathrm{NTC}=$ paille+bois sans termites; $\mathrm{NTW}=$ bois sans termites.

Les traitements de la même colonne ayant les mêmes sont pas statistiquement différents (Mando, 1997a, adapté).

\begin{tabular}{|l|l|l|l|l|l|l|l|l|l|l|l|}
\hline Treatment & \multicolumn{3}{|c|}{ \% Cover } & \multicolumn{3}{|c|}{ Biomass $\left(\mathrm{t}^{-1}{ }^{-1}\right)$} & \multicolumn{3}{|c|}{ Number of species } & Number of woody plants \\
\hline & 1993 & 1994 & 1995 & 1993 & 1994 & 1995 & 1993 & 1994 & 1995 & 1995 \\
\hline TS & $20.9 \mathrm{a}$ & $114.7 \mathrm{a}$ & $86.7 \mathrm{a}$ & $* *$ & $3.7 \mathrm{a}$ & $2.9 \mathrm{a}$ & $(3-13) \mathrm{a}$ & $(11-25) \mathrm{a}$ & $(26-35) \mathrm{a}$ & $417 \mathrm{a}$ \\
\hline TC & $11.2 \mathrm{a}$ & $76.8 \mathrm{~b}$ & $222.0 \mathrm{a}$ & $* *$ & $3.3 \mathrm{a}$ & $3.9 \mathrm{a}$ & $(1-15) \mathrm{a}$ & $(8-18) \mathrm{a}$ & $(18-32) \mathrm{a}$ & $665 \mathrm{a}$ \\
\hline TW & $11.2 \mathrm{a}$ & $68.9 \mathrm{~b}$ & $124.2 \mathrm{a}$ & $* *$ & $2.4 \mathrm{a}$ & $3.1 \mathrm{a}$ & $(1-15) \mathrm{a}$ & $(5-11) \mathrm{a}$ & $(18-30) \mathrm{a}$ & $417 \mathrm{a}$ \\
\hline NTS & $4.7 \mathrm{~b}$ & $30.7 \mathrm{c}$ & $83.6 \mathrm{~b}$ & $* *$ & $1.4 \mathrm{a}$ & $1.3 \mathrm{~b}$ & $(1-8) \mathrm{a}$ & $(6-10) \mathrm{a}$ & $(8-21) \mathrm{a}$ & $0 \mathrm{a}$ \\
\hline NTC & $8.2 \mathrm{~b}$ & $21.5 \mathrm{c}$ & $69.0 \mathrm{~b}$ & $* *$ & $1.4 \mathrm{a}$ & $1.1 \mathrm{~b}$ & $(!-7) \mathrm{a}$ & $(6-14) \mathrm{a}$ & $(6-20) \mathrm{a}$ & $0 \mathrm{a}$ \\
\hline NTW & $1.9 \mathrm{~b}$ & $33.1 \mathrm{c}$ & $35.5 \mathrm{~b}$ & $* *$ & $1.2 \mathrm{a}$ & $0.5 \mathrm{~b}$ & $(0-6) \mathrm{a}$ & $(2-12) \mathrm{a}$ & $(8-24) \mathrm{a}$ & $0 \mathrm{a}$ \\
\hline Ba & $0.0 \mathrm{~b}$ & $0.3 \mathrm{c}$ & $0.0 \mathrm{c}$ & $* *$ & $0.0 \mathrm{~b}$ & $0.0 \mathrm{~b}$ & $0 \mathrm{a}$ & $(0-2) \mathrm{a}$ & $0 \mathrm{a}$ & $0 \mathrm{a}$ \\
\hline
\end{tabular}

The vegetation performance was better on straw and composite plots, moderate on woody plots but was worst on unmulched (bare) plots. During consecutive years, the performance of the vegetation on termite plots increased but this phenomenon was more apparent on woody plots compared to straw plots. Straw had a quicker but shorter effect on vegetation performance. Bare plots remained bare throughout the experimental period.

Although mulch without termites did not significantly improve vegetation production of already crusted soils, it had some effect on plant growth by the improvement of microclimate conditions and entrapment of wind blow sediment that improves the rooting condition for plants.

Termites improved vegetation growth through two processes. Firstly by improvement of soil structure, water infiltration and water storage capacity and soil rootability. Improvement of water infiltration into soil was the most important mechanism of termites- mediated rehabilitation of crusted-soil primary production (Mando, 1997b). Secondly, by enhancement of nutrient release from the mulch into the soil. In semi-arid conditions termite activity plays a key role in nutrient cycling, especially through communition (i.e. breaking the organic material into a size that can be handled by micro-organisms) and the turn-over of organic material (Mando 1997a). Both processes are critical for land rehabilitation, but Mando (1997a) reported that the physical impact of termites in the rehabilitation of vegetation exceeds that of the chemical impact. The correlation coefficient $\left(\mathrm{r}^{2}\right)$ between vegetation performance and soil physical and chemical properties was 0.86 and 0.39 , respectively.

\section{Conclusions}

The experiments provided quantitative evidence that termites have a great role in modifying soil properties in the Sahel. The results proved that a simple application of organic material on waste lands can trigger termite activity. As a consequence of changed soil properties, completely degraded and crusted soils are now able to sustain a minimum biomass production $\left(2-4 \mathrm{tha}^{-1}\right)$. Using termites for land rehabilitation seems therefore an ecologically sustainable method as it requires only an initial investment in organic matter. However, the amount of mulch available at household or village level could be in some places a constraint, due to other uses (animal feed, fuel, construction, etc.). In practice, this implies that the area should be protected for some time.

The next step in validating this technology is through participatory on-farm research. This will bring awareness 
that, with proper management techniques and education, farmers can benefit from termites activities. At the same time, efforts should be intensified to show farmers that the negative effects of termites can be reduced, especially how to protect stored crop products as described by Iroko (1996). If such a research and extension strategy would prove to be successful, then farmers can make the pest work for them and, therefore, the termite in the Sahel would change from being an enemy to a friend.

\section{References}

Bachelier, G., 1978.

La faune du sol, son action.

ORSTOM, Paris, $391 \mathrm{pp}$.

Basppa, H. \& D. Rajagopal, 1991.

Physico-chemical properties of termite-modified soils due to foraging on dung in comparison with the surrounding soil.

Sociobiology 16: 175-185.

Bationo, A. \& A.U. Mokwunye, 1991.

Alleviating soil fertility constraints to crops production in West-Africa: the experience in the Sahel. In: A.U. Mokwunye (Ed.), Alleviating soil fertility constraints to increase crop production in West Africa.

Kluwer Academic Publishers, Dordrecht, pp. 195-215.

Black, H.I.J. \& M.J.N. Okwakol, 1997.

Agricultural intensification, soil biodiversity and agroecosystem function in the tropics: the role of termites. Applied Soil Ecology 6: 37-53

Berendse, F., B. Berg, \& E. Bosatta, 1987.

The effect of lignin and nitrogen on the decomposition of litter in nutrient poor ecosystems: a theoretical approach.

Canadian Journal of Botany 65: 1116-1120.

Chase, R. \& E. Boudouresque, 1987.

Methods to stimulate plant regrowth on bare Sahelian forest soils in the region of Niamey, Niger. Agriculture, Ecosystems \& Environment 18: 211-221.

Charles, R.W., 1979.

In: The pesticide manual: a world compendium.

British protection council; London, pp. 90-95.

Elkins, N.Z., G.V Sobol, T.J. Ward, \& W.G. Whitford, 1986.

The influence of subterranean termites on the hydrological characteristics of a Chihuahuan desert ecosystem. Oecologia 68: 521-528.

Fairhead, J. \& M. Leach, 1994.

Termites, society and ecology: perspectives from Mande and Central West Atlantic regions.

Paper presented to the African Studies Association Biennial Conference: University of Lancaster 5 - 7

September 1994.

Humphreys, G.S., 1994.

Bioturbation, biofabrics and biomantle: an example from the Sydney Basin.

In: A.J. Ringrose-Voase \& G.S Humphreys (Eds), Soil Micromorphology: studies in management and genesis. Developments in Soil Science 22: 421-436.

Iroko, A.F., 1996.

L'homme et les termitières en Afrique. Collections Economie et Développement.

Karthala, Paris, 298 pp.

Kaboré, V., 1994.

Amélioration de la production végétale des sols dégradés (zippéllés) du Burkina Faso par la technique des poquets (Zai).

Thèse de doctorat. EPFL, Lausanne, 230 pp.

Lal, R., 1987.

Tropical ecology and physical edaphology.

Wiley \& Sons, New York, 230 pp. 
Lee, K.E. \& R.C. Foster, 1991.

Soil fauna and soil structure.

Australian Journal of Soil Research 6: 745-775.

Lee, K.E. \& T.G. Wood, 1971.

Termites and Soils.

Academic Press, London, 251 pp.

Lobry De Bruyn, L.A. \& Conacher, A.J., 1990.

The role of termites and ants in soil modification: a review.

Australian Journal of Soil Research 28: 55-93.

Mando, A., L. Stroosnijder \& L. Brussaard, 1996.

Effects of termites on infiltration into crusted soil.

Geoderma 74: 107-113.

Mando, A., 1997a.

The role of termites and mulch in the rehabilitation of crusted Sahelian soils.

Tropical Resource Management Papers $\mathrm{N}^{0} 16$. Wageningen Agricultural University. Wageningen, $101 \mathrm{pp}$.

Mando, A., 1997b.

Effect of termites and mulch on the physical rehabilitation of structurally-crusted soils in the Sahel.

Land Rehabilitation and Development 8: 269-278.

Mando, A. \& R. Miedema, 1997.

Termite-induced change in soil structure after mulching degraded (crusted) soil in the Sahel.

Applied Soil Ecology 6: 241-249.

Valentin, C., 1995.

Sealing, crusting and hardsetting soils in Sahelian Agriculture. In: H.B. So, G.D. Smith, S.R. Raine, B.M. Schafer \& R.J. Loch (Eds.), International Symposium on sealing, crusting and hardsetting soils: productivity and conservation. DD>Australian Society of Soil Science, Canberra, pp. 53-76.

Wielemaker, W.G., 1984.

Soil forming by termites. A study in the Kissi area, Kenya.

$\mathrm{PhD}$ thesis, Wageningen Agricultural University. Wageningen. 251 p.

Wood, T.G., 1996.

The agricultural importance of termites in the tropics.

Agricultural Zoology Reviews 7: 117-150.

\section{Acknowledgements}

The authors would like to thank their colleagues at the Antenne Sahélienne, Ouagadougou, for critically reviewing this article. They would also like to thank prof. L. Brussaard and prof. L. Stroosnijder for supervising the research, and the reviewers for their valuable comments on earlier versions.

(C) NJAS 605, 1998 - Comments to: J.J.Neetson@AB.DLO.NL 